\title{
ВЛИЯНИЕ ЭКОЛОГИЧЕСКОГО СОСТОЯНИЯ НЕКОТОРЫХ ТЕРРИТОРИЙ РЕСПУБЛИКИ АДЫГЕЯ НА СОМАТИЧЕСКУЮ И СТОМАТОЛОГИЧЕСКУЮ ЗАБОЛЕВАЕМОСТЬ ДЕТЕЙ
}

\section{THE INFLUENCE OF THE ECOLOGICAL STATE OF SOME TERRITORIES OF THE REPUBLIC OF ADYGEA ON THE SOMATIC AND DENTAL HEALTH OF CHILDREN}

S. Ashkar

D. Shaova

S. Jafarova

Summary. The article contains an overview of the data contained in the literature and reflecting the level of impact of unfavorable environmental factors of the environment on the sanitary well-being of the child population of the Republic of Adygea, in terms of their somatic and dental health. In the publications under review, researchers draw a clear parallel between the environmental problems of the region and the incidence rate, and the severity of the observed pathologies.

Keywords: environmental factors, the level of childhood morbidity, dental morbidity.

\author{
Аикар Самир Серханович \\ Старший преподаватель, ФГБОУ ВО «Майкопский \\ государственный технологический университет», \\ 2. Maŭкon \\ dr.samirashkar@mail.ru \\ Шаова Данна Хамедовна \\ ФГБОУ ВО «Майкопский государственный \\ технологический университет», г. Майкоп \\ Джафарова Севил Бахтияр-кзы \\ ФГБОУ ВО «Майкопский государственный \\ технологический университет», г. Майкоп
}

Аннотация. Статья содержит обзор данных, содержащихся в литературных источниках и отражающих уровень воздействия неблагоприятных экологических факторов окружающей среды на санитарное благополучие детского населения Республики Адыгея, в части их соматического и стоматологического здоровья. В рассматриваемых публикациях исследователи проводят четкую параллель между экологическими проблемами региона и уровнем заболеваемости, а степенью тяжести наблюдаемых патологий.

Ключевые слова: экологические факторы, уровень детской заболеваемости, стоматологическая заболеваемость.

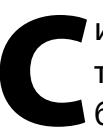

истематизированные на сегодняшний день в литературных источниках показатели санитарного благополучия населения позволяют проследить тесную взаимосвязь здоровья человека с качеством атмосферного воздуха.

Чем больше концентрация загрязняющих веществ в атмосферном воздухе, тем выше риск возникновения различных заболеваний. И это не только болезни дыхательной системы, но и нервные расстройства, и аллергические реакции. Увеличивается риск врожденных патологий новорожденных.

Проблемы санитарно-эпидемиологического благополучия российского населения были и остаются актуальными. Особое внимание при этом следует уделять здоровью детей. А уже на протяжении многих лет отмечается тревожная тенденция роста уровня заболеваемости детей. Статистические данные подтверждают высокий уровень заболеваемости и патологической пораженности. Наметившаяся тенденция по стабилиза- ции этих показателей еще не столь значима и не меняет в корне складывавшуюся на протяжении длительного времени ситуацию.

По-прежнему высока и продолжает повышаться заболеваемость детского населения в неблагополучных с экологической точки зрения регионах. Негативно отражаются такие неблагоприятные экологические условия и на состоянии стоматологического здоровья, в особенности - детского [4;7].

Целью нашего исследования является выявление зависимости заболеваемости детского населения Республики Адыгея от экологического состояния территории проживания.

В рамках поставленной нами цели был проведен анализ научных публикаций, имеющихся в открытом доступе, и отчетов Министерства здравоохранения Республики Адыгея, отражающих тенденции в заболеваемости детей региона в 2017-2019 гг. Данные об эколо- 
гической ситуации в регионе изучались по материалам доступных публикаций и аналитической отчетности Управления по охране окружающей среды и природным ресурсам Республики Адыгея за соответствующий период. Поиск научных публикаций осуществлялся на электронных ресурсах E-library и CyberLenink, отчетные данные получены с официальных сайтов органов исполнительной власти республики.

Республика Адыгея - южный регион, расположенный на площади 7791,8 тыс. км, с населением 463453 чел. (статистические данные за 2020 год).

Уровень санитарно-эпидемиологического благополучия населения республики, по данным управления Роспотребнадзора, определяется чистотой атмосферного воздуха, состоянием почв, уровнем загрязнения источников водоснабжения и радиационным фоном. Согласно проведенному анализу среди неблагоприятных экологических факторов максимальное влияние на уровень заболеваемости населения оказывает загрязнение атмосферного воздуха. Следует особо отметить, что большинство существующих проблем загрязнения атмосферы напрямую связано с антропогенным воздействием на окружающую среду, преимущественно - использованием автотранспорта. К приоритетным загрязнителям, контролируемым на территории республики вследствие превышения ПДК, относятся взвешенные вещества, оксид углерода, диоксид азота, формальдегид и др. [2].

По данным, содержащимся в докладе Управления Федеральной службы по надзору в сфере защиты прав потребителей и благополучия человека по Республике Адыгея динамика выбросов загрязняющих веществ в атмосферный воздух за последние 10 лет имеет позитивную тенденцию: доля проб атмосферного воздуха с содержанием загрязняющих веществ, превышающих ПДК снизилась в 2,85 раза. При этом в 2019 г. отмечено улучшение качества атмосферного воздуха по всем приоритетным загрязнителям воздуха городских и сельских поселений региона [3]. Наибольшее превышение предельно допустимых концентраций (ПДК) в 1,1-2,0 раза по оксиду углерода и диоксиду азота отмечалось в г. Майкопе и Тахтамукайском районе. Негативные последствия для здоровья, обусловленные присутствием вредных химических соединений в атмосфере, проявляются, как правило, при длительном их воздействии на человеческий организм.

Загрязнение оксидом углерода и взвешенными веществами приводит к проблемам с органами дыхания, заболеваниям сердечно-сосудистой системы, нарушениям в работе органов кроветворения и негативно отражается на нервной системе [6].
Не отвечает гигиеническим требованиям вода в централизованных системах хозяйственно-питьевого водоснабжения г. Майкопа и Тахтамукайского района. Отклонения от нормативных показателей отмечаются и по органолептическим характеристикам (мутности), и по санитарно-химическим (содержание железа выше ПДК в 1-3 раза). В п. Псекупс (г. Адыгейск) и в ст. Гиагинская содержание железа в питьевой воде централизованных систем водоснабжения составило от 1,1 до 2 ПДК [2].

Ввиду агропромышленной направленности региона особое внимание уделяется загрязнению почвы, особенно в районах промышленного производства. Имеются публикации, посвященные данной проблеме в районах, прилегающих к химическому комбинату в г. Белореченске (Краснодарский край): территория г. Майкопа и Гиагинского района республики. Авторы указывают, что содержание в почве цинка выше ПДК в 1,5-1,9 раза. На втором месте по загрязняющему воздействию на почву - хром. На значительных территориях республики почвы загрязнены свинцом, никелем, ванадием и другими опасными веществами, что влечет за собой повышение токсикации выращиваемой сельскохозяйственной продукции.

В числе наиболее распространенных заболеваний детского населения Республики Адыгея (общая заболеваемость) - болезни дыхательной системы, костно-мышечной системы и системы пищеварения. Согласно отчетам Министерства здравоохранения региона, в г. Майкопе наблюдается превышение среднего показателя заболеваемости детей в возрасте 0-14 лет и подростков 15-17 лет [5].

В изученных источниках имеются единичные публикации, содержащие оценку обусловленности соматического здоровья детей Республики Адыгея экологическим состоянием территории проживания. Агиров А.X. с соавт. (2011) изучили экологические факторы, оказывающие значимое воздействие на показатели, характеризующие уровень заболеваемости населения республики: пробы атмосферного воздуха, питьевой воды, почвы, воды водоемов. Отклонения от ПДК по атмосферному воздуху (в пределах 1-3) были выявлены в городах региона (по взвешенным частицам и оксиду углерода). Превышение содержания железа в питьевой воде (в пределах 1-3 ПДК) выявлены в городах Майкоп и Адыгейск, населенных пунктах Тахтамукайского и Гиагинского районов. Данные показали, что оптимального содержания фтора и йода не было ни в одном источнике питьевой воды, что является одной из основных причин повышенной заболеваемости кариесом зубов и эндемическим зобом (заболеваемость кариесом в РА находилась на уровне 98\%) [1]. Чернов П.Ю. в своей ра- 
боте проводит параллели между загрязнением почвы региона и уровнем заболеваемости острыми кишечными инфекциями. В выводах автор указывает, что из-за избыточной концентрации вредных веществ в почве наблюдается ухудшение здоровья населения, а также проявляются не характерные ранее для районов региона острые кишечные заболевания [8].

Размещенных в открытом доступе научных публикаций, затрагивающих проблему детского стоматологического здоровья в разрезе районов Республики Адыгея и содержащих аргументированную оценку последнего, практически нет. Единственная доступная информация представлена данными Кузьминой Э.М. с соавт. (2019) [8]. Данные о стоматологическом здоровье детей региона авторы получили в процессе эпидемиологического обследования населения России. Содержание фтора в воде, по данным авторов, варьируется в пределах 0,07-0,09 мг/л.

При этом заболеваемость кариеса молочных зубов у детей в г. Майкоп достигает $82 \%$ (при индексе кпу =4,5). Высшая степень распространения, а также интенсивность кариеса молочных зубов выявлена в Гиагинском районе $(100 \%$, при индексе кпу $=8,1)$, наименьшая - в г. Адыгейске и Тахтамукайском районе $(75 \%$, при индексе кпу=3,15-4,65). Однако, к 12-15 годам ситуация резко ухудшается. Во всех районах региона рас- пространенность кариеса постоянных зубов составляет 92-95\%, а индекс КПУ имеет следующие значения: в Майкопе - 4,56 (в 12 лет) и 7,18 (в 15 лет), в г. Адыгейске - 4,2 и 7,25, в Гиагинском районе - 5,34 и 6,96, в Тахтамукайском районе - 6,3 и 7,05 соответственно.

Подытоживая все вышеуказанное, приходим к следующим выводам:

- заболеваемость детей Республики Адыгея соматической и стоматологической патологией напрямую зависит от уровня экологического состояния территории;

- нет возможности оценить влияние экологических факторов на конкретные нозологические единицы на всей территории региона, поскольку в открытом доступе не представлено статистически достоверных данных по заболеваемости детей (соматической и стоматологической) в разрезе районов.

Изученные данные, представленные в открытом доступе, позволяют сделать вывод о наличии необходимости и перспективности проведения дальнейших исследований по выявлению степени влияния неблагоприятных экологических условий на соматическое и стоматологическое здоровье детского населения в разрезе территориальных образований Республики Адыгея.

\section{ЛИТЕРАТУРА}

1. Агиров А.Х. Экология и здоровье детского и подросткового населения Республики Адыгея / А.Х Агиров, Н.А. Агаджанян, Р.Ш. Ожева, С.П. Лысенков // Фундаментальные исследования.— 2011.— № 9-2.—C. 196-201.

2. Государственный доклад «0 состоянии санитарно-эпидемиологического благополучия населения в Республике Адыгея в 2019 году» / Управление Федеральной службы по надзору в сфере защиты прав потребителей и благополучия человека по Республике Адыгея. — Майкоп, 2020.— 259 с.

3. Капранов, С.В. Влияние загрязнителей атмосферного воздуха на заболеваемость и распространенность болезней среди детского населения в промышленном городе / С.В. Капранов, Д.В. Тарабцев // Здоровье и окружающая среда. - 2017. — № 27. - С. $26-30$.

4. 0 состоянии здоровья населения и организации здравоохранения в Республике Адыгея за 2019 год: Доклад / Майкоп, 2020. - 134 с. Электронный ресурс: URL: http: www.adygheya.ru/ministers/departments/ministerstvo-zdravookhraneniya/ deyatelnosti- ispolnitelnogo/ktera-0-de.php (дата 0бращения: 08.12.2020)

5. 06 экологической ситуации в Республике Адыгея за 2019 год: Доклад / Майкоп, 2020. - 179 с. Электронный pecypc: URL: http://www.adygheya.ru/ ministers/departments/upravlenie-po-okhrane-okruzhayushchey-sredy-i-prirodnym-resursam/informatsi/doklady/ (дата обращения: 18.12.2020)

6. Очерет Н.П. Современные проблемы антропогенной деградации почв сельскохозяйственного назначения Республики Адыгея / Н.П. Очерет, Т.Г. Туова, Ф.В. Тугуз // Вестник Адыгейского государственного университета. Серия 4: Естественно-математические и технические науки. - 2015. - № 2 (161). - C. 102-109.

7. Стоматологическая заболеваемость населения России / Э.М. Кузьмина, 0.0. Янушевич, И.Н. Кузьмина. - М.; МГМСУ, 2019. - 304 с., ил.

8. Чернов П.Ю. Состояние почвы в Республике Адыгея и ее влияние на здоровье населения / П.Ю. Чернов // Материалы VII Международной студенческой научной конференции «Студенческий научный форум». URL: http://scienceforum.ru/2015/article/2015008060»>http://scienceforum.ru/2015/ article/2015008060< (дата обращения: 18.12.2020).

(c) Ашкар Самир Серханович (dr.samirashkar@mail.ru ),

Шаова Данна Хамедовна,

Джафарова Севил Бахтияр-кзы.

Журнал «Современная наука: актуальные проблемы теории и практики» 